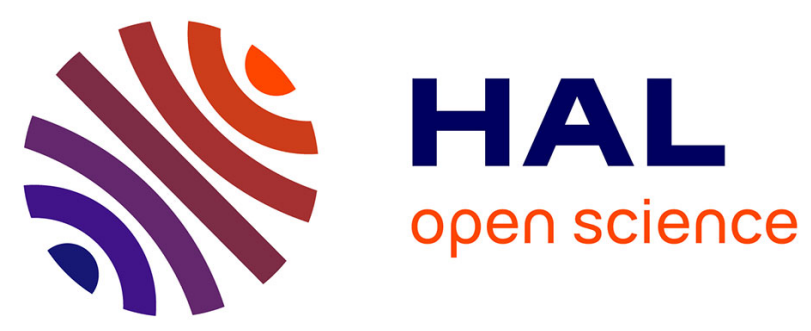

\title{
The role of the Mediterranean networks of cooperative research in animal production in favor of innovation: situation and outlooks for the future
}

\author{
Jean-Paul Dubeuf, Jean Boyazoglu
}

\section{- To cite this version:}

Jean-Paul Dubeuf, Jean Boyazoglu. The role of the Mediterranean networks of cooperative research in animal production in favor of innovation: situation and outlooks for the future. New trends for innovation in the mediterranean animal production, 129, Wageningen Academic Publishers, 345 p., 2011, European Association for Animal Production Publication, 978-90-8686-726-4. hal-01222885

\section{HAL Id: hal-01222885 \\ https://hal.science/hal-01222885}

Submitted on 30 Oct 2015

HAL is a multi-disciplinary open access archive for the deposit and dissemination of scientific research documents, whether they are published or not. The documents may come from teaching and research institutions in France or abroad, or from public or private research centers.
L'archive ouverte pluridisciplinaire HAL, est destinée au dépôt et à la diffusion de documents scientifiques de niveau recherche, publiés ou non, émanant des établissements d'enseignement et de recherche français ou étrangers, des laboratoires publics ou privés. 


\title{
THE ROLE OF THE MEDITERRANEAN NETWORKS OF COOPERATIVE RESEARCH IN ANIMAL PRODUCTION IN FAVOR OF INNOVATION : Situation and outlooks for the future
}

\author{
Jean-Paul DUBEUF, * Jean BOYAZOGLU** \\ *INRA -SAD, LRDE, F-20250 Corte._dubeuf@corte.inra.fr \\ **F-06500Menton@mail : jean.boyazoglu@wanadoo.fr
}

\begin{abstract}
The animal production sector in the Mediterranean, as in other areas but with specific characteristics has to face new challenges related to environment, productivity and social issues. By considering the hypothesis that more and urgent innovation is needed, to solve the complexity of these problems, the organization, activities and production of some permanent networks of Cooperative Research in Animal Production are described and their possible role in these process are discussed. It would mean that these networks could involve cooperating scientists from several disciplines and other "actors". The development of networking would be probably a major stake to enlarge a more strategic and open approach of the questions to answer. The present disciplinary organization, the real involvement of a variety of actors, their impact on innovation and some suggestions for their evolution are analyzed to outline the difficulties existing to change the situation.
\end{abstract}

Key words: Networking, Innovation, Organization, Mediterranean, Animal Production

\section{Introduction : The main challenges of Animal production around the Mediterranean and the creation of the Mediterranean networks}

Animal Science has built its legitimacy in the last 50 years through its results to increase the animal performances in controlled systems. Many innovations leading to increase productivity were a great success both in meat and milk production. For the animal production sectors, the Mediterranean production systems have often been considered marginal. The dominant models were exogenous and the Mediterranean characteristics, know how and practices were not involved in them. At a general point of view, the external intensive production systems have been promoted and developed as a priority: feedstuffs fed cattle or dairy cows, intensive pig and poultry are now a majority and have gathered most of the investments. These systems have few territorial links and are high consumers of energy, water and imported food (Benoit, 2007).

On the other side, it is well known that the Mediterranean production systems, based on the use of rangelands, local breeds and local practices, and a low specialization of animal production and crops have been considered as being not enough productive and for this reason as "relics of the past". For more or less 30 years, the "Public Services" have only lightly changed their direction with the promotion and certification of local products, actions in favor of pastoralism both in the Northern and Southern banks. In spite of a real success for pigs in Spain, sheep and goat or buffalo cheeses in France, Italy, Spain Cyprus and Greece, the private investment is still very low and the lack of coordination between Research, Administration, Training, Professional Organizations and Industry has been often underlined (Couzy et al., 2000).

It is to take in account these specific situations and their diversity that several scientific networks have been created for more than 30 years thanks to the awareness of some academics, researchers in animal production and pioneers in their speciality (from France, and Germany at the beginning but followed by others from Italy, Spain, Greece and also from Eastern Europe) but also very close to extension activity and to the world of breeders and professional organizations. In the lights of their academic position, they could have acted in their own name but also with the institutional support of their organization. 
We have considered the fact that the Mediterranean region is at the heart of geostrategical, demographic, social and environmental stakes not limited to the Agricultural sector : organization of trade and exchanges between the North and Southern region; migratory and social problems related to demography and economical imbalance ; erosion of soils and desertification of many areas (both in North and South) ; lack of water and management of water resources ; food autos ufficiency (South); disappearance of cultural heritage and know how. By considering these stakes, we will analyze the activity and organization of these networks, how their community has evolved and discuss in what way they could increase their participation in the innovating process .

\section{A short history of the Mediterranean Networks of Cooperative Research in Animal Production}

The dynamism of networking in the Mediterranean Animal Production has been a reality during several decades and several groups have shown to be very active since the years 70-80's with many publications, meetings, and thematic exchanges. The initial objective was to improve consultation and dialogue around the mutual understanding of the challenges of researches at economic and geopolitical levels but with individual spontaneous initiatives. We have considered 3 permanent supports for networking involving specifically Research, Development in Animal Production in the Mediterranean : EAAP, CIHEAM and FAO. All other existing networks are not focused in this geographical area. We have checked that there is no other global organization specialized in the Mediterranean region

The $\mathrm{EAAP}^{1}$ and their Mediterranean Group :

According to its web site (2008), the main aims of EAAP are to promote, for the participating European and Mediterranean countries, "the advancement of scientific research, sustainable development and systems of production; experimentation, application and extension (...) by means of active co-operation between its members and other relevant international and national organisations," and to "encourage the involvement of young scientists and technicians." This Mediterranean working group has mainly organized thematic symposiums as recently in Badajoz (on quality products in 1996 ), in Hammamet (on dairy sectors in 2000), in Santarem (2006) and now in Corte (2008). This working group has no formal institutional constitution and is working on the basis of the volunteer involvement of the participants.

The FAO-CIHEAM networks :

These networks are supported officially by two institutions, CIHEAM and FAO.

- CIHEAM is organized as a network of 13 countries and 4 national institutions for Mediterranean research and high studies sharing strategic thematcs, Bari, Chania, Zaragoza (for Animal Production), Montpellier (for Economics, Development and Public policies).

- FAO is the Agency of the United Nations for Food and Agriculture and has supported the Mediterranean networks through the system of ESCORENA Networks and the Regional Office for Europe. It is now more oriented towards the Southern Basin and developping countries.

In Animal Production, FAO and CIHEAM have supported mainly 4 networks on Cooperative Research and Development : the network on sheep and goats (with 3 sub networks, nutrition, production systems and genetic resources) involves 225 researchers from 60 institutions from 35 countries; the network on pasture (subnetworks on plain pastures, Mediterranean forage resources and mountain pastures); the network on local rabbit breeds and the network on Mediterranean pig created by 5 institutions from 4 countries after the conclusions of a Research project. These networks are also working on a volunteer base.

The more important one on sheep and goats was created in 1979 and reorganised in 1991 with a clear displayed objective for development : to "define research objectives, to improve the income of farmers, support sustainable production systems, create new products, promote cooperative research projects, give information to all users and organise symposiums and

\footnotetext{
1 European Association of Animal Production
} 
meetings".

\section{Discussion and conclusion : Present organization, present difficulties and possible changes in favor of innovation}

These networks were created as a support for training within a geographical and a political environment and with an institutional international (FAO, CIHEAM, EAAP) or National (INRA, GTZ, IZC, IZCS) formalization but they have been a success above all thanks to a real individual involvement. It seems to be the key point to explain their success but also their ambiguity. During several decades, they have produced key documents and real adding value thanks to the personal enthusiasm of their leaders, all with a global vision and strong local roots (considered as a key for success in networking by Torre, 1996). They have created very diverse and dynamic communities with strong interpersonal and professional relations.

To be accepted by their institutional support, their activity has been always presented for Research and Development with strong relation to extension services, a wide spread information, consultancy for decision making, etc... During their meetings it has often been possible to build punctual collective projects but often without achieving long term activities and programs. In other words and due to their structural situation there is a gap between the showing off and the reality and in most cases they have worked as more classical scientific associations:

- The symposiums and seminars have been the main chance to meet and to interact collectively, being still easy to organize with local and institutional support.

- Most of the services and permanent activities have worked irregularly, (news letters, mre recently web sites) by lack of permanent financial or human resources.

- Very little specific financial support given by the supporting organizations to develop the program

- Being without financial stakes, they have no real evaluation nor real institutional steering with a danger of auto legitimacy.

Aware of such a situation, the sheep and goat networks and EAAP have supported formally the creation of CIRVAL, in 1993, as a Resource Centre dedicated to information and realizing their own objectives but with little involvement of the Institutions or the members of these networks to associate their national or professional organizations in a real multilateral financial support (Dubeuf, 2006).

The recent evolution has also changed the profile of the scientists in Animal Production, more specialized, with more academic constraints and less relations to the professional and extension services. If we observe a generally good participation during the symposiums, the permanent involvement of the younger scientists in exchanges and actions is less constant. Although no specific measuring has been done for these networks, such a reality is coherent with the results of Barbier et al. (2008) showing (for an other network) that only 5\% of the authors of the IFSA ${ }^{2}$ symposiums have produced $36 \%$ of the communication ${ }^{3}$ and wondering if the IFSA network is a real community. In the case of the FAO - CIHEAM network on sheep and goats, the number of members has increased from 192 (Morand-Fehr et al., 1996) to 225 in 2008 but with less permanent active participation.

Historically, in spite of a strong awareness of the realities of the Mediterranean region, these networks had a strong mono-disciplinary bio - technical origin (mainly Genetics, Nutrition, Physiology of Reproduction) ; their vision was directly a consequence of the up and down approach of innovation. But, although this pattern is still deeply in the mind of many, innovation is today more considered at a larger extend. The present vision of innovation is more this of a collective construction to face the realties and complexity of the problems and stakes, with simultaneous environmental, social and economical issues. Although, colloquially, the word "innovation" is often used as synonymous with the output of the process, an innovation is not only technological and

International Farming Systems Association

Many partipants publish one or two times only without continuity 
"scientific" but can be also at an organizational or commercial level or all element of change. Animal production (as other sectors) will have to face important challenges, in the near future and perhaps more dramatically in the Mediterranean regions (and in arid areas). So It seems logical to consider that more and more innovation will be needed urgently at all levels. How the networks could follow these new challenges and patterns? But in spite of several punctual initiatives to introduce new questions and debates related to the socio-economical conditions of animal production and their relations to the application of scientific results, the activity is still presently above all academical and focused on bio - technical results.

According to Callon, (1996) innovation needs also the participation of all the actors to be accepted but also a system of exchanges to enable contradictory discussions and debates. We could logically wonder if these networks could change and develop these exchanges as the basis of their activity. Firstly, new scientific knowledge is not equal to innovation and the personal or professional motivation of the scientists participating these networks in favor of these orientations is not sufficient. Secondly, such activities are presently not always well acknowledged for the scientific evaluation and management of their careers. Besides, through several examples, it seems that very often the participation of the extension services or professional services is announced by the scientists without their real involvement .

Nevertheless, other types of organizations are needed. Between Research and Development, Le Masson et al. (2006) have proposed to insert an other function, Innovating Conception at the company level. The hypothesis is that specific organizations and tools would be needed to transform knowledge (and especially scientific knowledge) in real applied innovations for the companies (farms or organizations) with the support of development and extension agents. Innovation is no more a question for isolated people; it would be a full collective activity that require to integrate technical, scientific and management patterns. That does not mean that the present networks could substitute these new functions for the present ones simply by voluntarist declarations. We have to be aware that developing innovative approaches (and so achieve their declared objectives) is not only dependent of the internal forces and good will of the leaders of these networks and that we can not order to develop bridges with social and human sciences.

There is still a long way to make these views fully accepted particularly in the Mediterranean basin. At the contrary, in case of lack of initiative, the permanence of these networks could be threatened at a short term. These networks could more easily realize Science in Society if more complex organizations involving both economic actors and politics would be created concretely with a clear political and economical support. The concrete planning of such new organizations has been more advanced when there is a strong economic sector as the dairy industry for instance. In these case, it would push their activity, give more faith, real sense and enthusiasm for innovative practices in these exchanges.

\section{References}

Barbier, M., Garandel Batifol, V., Bompart, M., 2008. A textual Analysis of Scientometric mapping of the dynamic of kowledge in and around the IFSA community. communication presented in the "8th IFSA European Symposium; 6to 10th July, 2008; Clermont Ferrand.

Dubeuf, J-P, 2006. 10 ans d'activités au CIRVAL; enseignements de l'expérience et propositions pour le futur ; 30 p. (rapport interne INRA non publié)

Le Masson, P., Weil B., Hatchuel V., 2006. Les processus d'innovation - conception innovante et croissance des entreprises, 470 p. Hermes Sciences éditeurs, Paris.

Couzy, Ch.,2000. L'Organisation et le fonctionnement des Services techniques et de Conseil à l'élevage ovin-caprin en Europe du Sud. CIRVAL, 53 pp..

Morand-Fehr, P., Gabina D., Rubino, R. 1996, The FAO-CIHEAM network on sheep and goats activities on smaal ruminants products ; in « Les dossiers du CIRVAL, $\mathrm{n}^{\circ} 1$ Information et innovation pour les filières dispersées"; $\mathrm{p} 117$. Corte.

\section{http://www.ciheam.org}

http://www.eaap.org 